\title{
Correction to: Assessment of wheat genotypes based on genotype-by-environment interaction for durable resistance to spot blotch disease in hot spot
}

\author{
N. Chattopadhyay ${ }^{1}$ (D) R. Mandal ${ }^{2} \cdot$ A. Roy ${ }^{1} \cdot$ P. M. Bhattacharya ${ }^{1} \cdot$ A. K. Chowdhury ${ }^{1}$
}

Published online: 18 May 2021

๑) Akadémiai Kiadó Zrt. 2021

\section{Correction to: Cereal Research Communications \\ https://doi.org/10.1007/s42976-021-00164-y}

In the Discussion section in the initial online publication, there was a subheading Discussion, which has been corrected to read Conclusion. The original article has been corrected.

The original article can be found online at https://doi.org/10.1007/ s42976-021-00164-y.

N. Chattopadhyay

a-2017-16-d@ubkv.ac.in;

chattopadhyaynivedita92@gmail.com

1 Department of Plant Pathology, Uttar Banga Krishi Viswavidyalaya, Coochbehar 736165, India

2 Department of Genetics and Plant Breeding, Uttar Banga Krishi Viswavidyalaya, Coochbehar 736165, India 